\title{
Team turnover and task conflict: A longitudinal study on the moderating effects of collective experience
}

Citation for published version (APA):

Kuypers, A. P. A., Günter, H., \& van Emmerik, I. H. (2018). Team turnover and task conflict: A longitudinal study on the moderating effects of collective experience. Journal of Management, 44(4), 1287-1311. https://doi.org/10.1177/0149206315607966

Document status and date:

Published: 01/01/2018

DOI:

10.1177/0149206315607966

Document Version:

Publisher's PDF, also known as Version of record

Document license:

Taverne

Please check the document version of this publication:

- A submitted manuscript is the version of the article upon submission and before peer-review. There can be important differences between the submitted version and the official published version of record.

People interested in the research are advised to contact the author for the final version of the publication, or visit the DOI to the publisher's website.

- The final author version and the galley proof are versions of the publication after peer review.

- The final published version features the final layout of the paper including the volume, issue and page numbers.

Link to publication

\footnotetext{
General rights rights.

- You may freely distribute the URL identifying the publication in the public portal. please follow below link for the End User Agreement:

www.umlib.nl/taverne-license

Take down policy

If you believe that this document breaches copyright please contact us at:

repository@maastrichtuniversity.nl

providing details and we will investigate your claim.
}

Copyright and moral rights for the publications made accessible in the public portal are retained by the authors and/or other copyright owners and it is a condition of accessing publications that users recognise and abide by the legal requirements associated with these

- Users may download and print one copy of any publication from the public portal for the purpose of private study or research.

- You may not further distribute the material or use it for any profit-making activity or commercial gain

If the publication is distributed under the terms of Article $25 \mathrm{fa}$ of the Dutch Copyright Act, indicated by the "Taverne" license above, 
Journal of Management

Vol. 44 No. 4, April 2018 1287-1311

DOI: $10.1177 / 0149206315607966$

(C) The Author(s) 2015

Reprints and permissions:

sagepub.com/journalsPermissions.nav

\title{
Team Turnover and Task Conflict: A Longitudinal Study on the Moderating Effects of Collective Experience
}

\author{
Tom Kuypers \\ Fontys International Business School \\ Hannes Guenter \\ Hetty van Emmerik \\ Maastricht University
}

Team turnover can be harmful to a team in many ways. This study examined whether a team's collective experience (team organizational tenure) attenuates the association between team turnover and task conflict changes. Differing from prior research, our study used a longitudinal design to assess the effects of team turnover, accounting for the competence of those leaving the team. We built on context-emergent turnover theory and tested a random coefficient growth model by utilizing data from 74 health-care teams. We found support for the hypothesized interaction: The more collective experience the team had, the less likely it was that team turnover associated with increases in task conflict. We discuss implications for theory and practice.

Keywords: team turnover; collective experience; organizational tenure; task conflict; CET theory; longitudinal design; random coefficient growth model

Team turnover describes the collective outflow of human capital from a team (Hausknecht \& Trevor, 2011; Nyberg \& Ployhart, 2013). The higher the number of team members who leave a team over a certain time period, the more harm team turnover can do to that team. This is because team turnover drains human resources, disrupts coordination, and makes the reassignment of tasks and responsibilities necessary (Van der Vegt, Bunderson, \& Kuipers, 2010; Wittenbaum, Vaughan, \& Strasser, 1998). These changes and the subsequent efforts

Acknowledgment: This article was accepted under the editorship of Patrick M. Wright.

Corresponding author: Tom Kuypers, Fontys International Business School, Tegelseweg 255, 5912 BG Venlo, The Netherlands.

E-mail: t.kuypers@fontys.nl 
aimed at recoordinating team processes are likely to involve discussions and disagreements about how to organize team tasks. In other words, team turnover is likely to cause task conflicts amongst the remaining team members. Task conflicts describe disagreements that focus on a specific task and involve discussions about the strategy of the team and how to tackle complex team tasks (Jehn \& Mannix, 2001). Although we are certainly not the first to point to the association of team turnover and task conflict (see Arrow \& McGrath, 1993; O'Connor, Gruenfeld, \& McGrath, 1993; Van der Vegt et al.), we extend current literature by studying team turnover over time and by using a measure of team turnover that accounts for the differences in competence among team members.

With our study, we aim to contribute to the understanding of the team turnover-team conflict association by addressing a set of research issues that have so far received little empirical attention. First, team turnover research has remained largely static in that scholars have used mainly cross-sectional research designs to investigate the effects of team turnover (see Van der Vegt et al., 2010). Hausknecht and Trevor, for instance, observed that "the temporal dynamics of collective turnover truly have received almost no attention" (2011: 380). Second, there is reason to believe that the effects of team turnover are dependent on other team-level characteristics, including human capital resources (e.g., Nyberg \& Ployhart, 2013). Scholars, accordingly, have called for more research into such moderating factors (e.g., Hausknecht \& Trevor; Hancock, Allen, Bosco, McDaniel, \& Pierce, 2013). For instance, it may well matter whether employees leave a team that is composed of highly experienced team members (that have been with the organization for a while) or whether team members that remain in the team are relatively new to an organization and still learning the ropes. Third, team turnover research has typically used the quantity of leavers as a measure of turnover. Although this research has helped generate important insights into the effects of team turnover (see, e.g., Kacmar, Andrews, Van Rooy, Steilberg, \& Cerrone, 2006; Van der Vegt et al.), it seems that quantity measures of turnover are incongruent with recent theorizing on team turnover (Nyberg \& Ployhart).

In addressing these issues and in building on context-emergent turnover (CET) theory (Nyberg \& Ployhart, 2013), we first develop an account of how team turnover associates with changes in task conflict. More specifically, we modeled team turnover as a time-varying predictor of task conflict changes (e.g., increases in task conflict over time). This involved measuring both team turnover and task conflict repeatedly over time. CET theory is particularly well suited as a foundation for our study in that it makes specific predictions on unitlevel effects of collective turnover and how these effects may play out over time. ${ }^{1}$ Second, we hypothesize that collective experience (measured via the average organizational tenure in a team) helps teams cope with team turnover, which is consistent with CET theory. The more organizational experience a team possesses, the less likely it should be that team turnover associates with increases in task conflict. This is because teams with high organizational tenure know how to mitigate the potentially negative implications of turnover better (e.g., temporary increase in workload), for instance, by accessing additional resources and obtaining organizational support. Third, we introduce a quality-adjusted measure of team turnover in order to provide a measure of turnover that aligns with CET theory (Nyberg \& Ployhart), the guiding theory used for developing our hypotheses. Fourth, we used a longitudinal (repeated-measures) design with five measurement points (spanning a 2-year period) and random growth modeling techniques to adequately test for the hypothesized effects. In doing 
so, we address calls in the literature to generate novel insights into turnover by collecting longitudinal data and by using analytical techniques (e.g., growth modeling) that have so far remained underused (Allen, Hancock, Vardaman, \& McKee, 2014). We used data from 74 teams belonging to a health-care organization in the Netherlands to provide an empirical test of our hypotheses on the longitudinal effects of team turnover.

\section{Conceptual Background}

\section{Emergence of Turnover at the Aggregate Level}

The concept of turnover is not new and has been defined by March and Simon (1958) as the departure of an employee from an organization. Consistent with this definition, turnover research has focused predominantly on individual turnover and its antecedents and effects. For instance, Lee and Mitchell (1994), in their unfolding model of individual turnover, described four distinctive employee decision paths. Mobley (1982) suggested that individual turnover might disrupt performance when an experienced employee leaves, when time is lost in an attempt to secure a replacement, or when an employee who intends to leave becomes less efficient. Price (1989) found that the departure of poorly performing employees (functional turnover) may actually have favorable effects on performance. Allen, Bryant, and Vardaman (2010) discussed several misconceptions about turnover and introduced a set of new practices to handle turnover by using evidence-based strategies.

Although research has focused primarily on individual turnover and its consequences, more recently, scholars have also begun studying collective turnover, including team turnover (see Hancock et al., 2013; Hausknecht \& Holwerda, 2013; McElroy, Morrow, \& Rude, 2001; Park \& Shaw, 2013; Shaw, Gupta, \& Delery, 2005; Van der Vegt et al., 2010). Team turnover is defined as the "aggregate levels of employee departures that occur within groups, work units, or organizations" (Hausknecht \& Trevor, 2011: 353). Team turnover research is particularly interested in understanding how turnover changes over time and how these dynamics in turnover affect team performance. Call, Nyberg, Ployhart, and Weekley (2015), for example, investigated when, why, and how turnover rate change influences unit performance. Although research on team turnover often uses individual-level theory to make predictions about unit-level effects (Hausknecht \& Trevor), team turnover and individual turnover constructs are conceptually distinct (Nyberg \& Ployhart, 2013) and should be treated as such. Individual turnover research explores the motives and performance implications of a single employee leaving (or considering leaving) an organization, whereas team turnover takes into account the aggregate of individual turnover decisions. The consequence of individual turnover is the loss of a single employee's knowledge and skills, often assessed in replacement costs and individual productivity losses (Nyberg \& Ployhart). Team turnover, instead, depletes a team's knowledge, skills, abilities, and other characteristics (KSAOs), impairs social relationships, and makes reconsidering the distribution of responsibilities within a team necessary (Shaw, 2011). Hausknecht and Trevor therefore argue that generalizing individual-level theories of turnover to the team level is not appropriate and that new theory needs to be developed.

In responding to this call, Nyberg and Ployhart (2013) introduced CET theory. CET theory posits that individual-level turnover and team-level turnover are different constructs, so that assumptions made about individual-level turnover may not apply to team-level (higher-level) 
turnover (Kozlowski \& Klein, 2000). Consistent with CET theory, our analysis is not restricted to the quantity of team turnover but, instead, also accounts for the quality in team turnover in terms of human capital resource depletion (Nyberg \& Ployhart; Reilly, Nyberg, Maltarich, \& Weller, 2013). This appears necessary because quantity and quality of turnover may act together to determine the magnitude and direction of team turnover consequences (Nyberg \& Ployhart). Furthermore, we do not distinguish between voluntary, involuntary, and functional team turnover, which is in line with CET theory. This is because irrespective of the type, team turnover depletes human capital and interrupts the routine functioning of teams (Nyberg \& Ployhart). We acknowledge the possibility that team turnover may be functional (i.e., a poorly performing member leaves a team) but emphasize that team turnover will still yield task conflicts because tasks and responsibilities need to be redistributed within the team, independent of the reason or the functionality of the turnover.

\section{Task Conflict and Its Dynamic Nature}

Team conflicts describe interpersonal processes (Marks, Mathieu, \& Zaccaro, 2001) in which "one party perceives that its interests are being opposed or negatively affected by another party" (Wall \& Callister, 1995: 517). This involves the awareness among team members of the differences in interests and the incompatibility of preferences (Jehn \& Mannix, 2001). Building on earlier research (Guetzkow \& Gyr, 1954), Jehn (1995) distinguished between task and relationship conflict. Here, we focus on task conflict, which arises when team members hold different opinions about the work to be done and disagree about taskrelated aspects, such as resource allocation, task strategy, policy development, and how to solve complex problems (Janssen, Van De Vliert, \& Veenstra, 1999; Jehn \& Mannix). We focus on task conflict (as opposed to relationship conflict) because it should be a direct outcome of the reassignment of tasks and responsibilities implicit in team turnover. Relationship conflict, instead, is more likely to serve as a rather distal outcome of team turnover, possibly mediated via task conflict (e.g., Simons \& Peterson, 2000). Additionally, prior research indicates that task conflict is not only common at work but also very difficult to manage (see Spell, Bezrukova, Haar, \& Spell, 2011). Finally, from a theoretical point of view, it also seems plausible to focus on task conflict because task conflict, more than relationship conflict, can be predicted by using human capital resource theory (which is central to CET theory).

Research on team conflicts has focused on static levels of task conflict, paying less attention to the temporal patterns in task conflict. Notable exceptions include research from Jehn and Mannix (2001) and from Greer, Jehn, and Mannix (2008). Jehn and Mannix used Gersick's (1998) dynamic equilibrium theory to study how high- and low-performing groups differ in terms of conflict. They found that high-performing teams experienced an increase in task conflict around the midpoint of a project followed by a decrease in task conflict towards the project's end. Greer et al. showed how different kinds of conflict relate over time and how conflict escalation depends on whether teams are successful in resolving conflicts quickly. In both studies, the authors examined temporary teams (i.e., teams that exist only for the fulfillment of a specific task), whereas our focus is on ongoing teams, that is, teams that have no predefined date at which they go out of existence (see Bradley, White, \& Mennecke, 2003). 


\section{Team Turnover and Task Conflict in Teams}

Apart from some exceptions (e.g., Hirst, 2009), research finds that team turnover has negative implications. Hirst showed that membership change positively associated with open discussion and team performance in newly formed teams. In contrast to this finding, various other studies have shown that team turnover negatively relates to, for instance, social integration (Van der Vegt et al., 2010), service quality perceptions (Hausknecht, Trevor, \& Howard, 2009), unit performance (McElroy et al., 2001), effectiveness in self-managing work teams (Van der Vegt et al.), team and organizational performance (Shaw, Duffy, Johnson, \& Lockhart, 2005), and team learning (Akgün \& Lynn, 2002). In the current study, we focus on task conflict as the outcome. Although arguably a direct and important consequence of team turnover (O'Connor et al., 1993), task conflict has rarely been studied in the team turnover literature.

CET theory (Nyberg \& Ployhart, 2013) predicts a negative association between collective turnover (accounting for the quantity and quality of leavers) and unit performance. This influence on unit performance is most likely to occur because team turnover complicates team coordination and creates additional responsibilities for those who remain part of the team (Nyberg \& Ployhart). Team turnover is associated with task conflict because those remaining with the team often need to take on additional responsibilities. When employees leave a unit, all of their contributions to the team leave as well (Nyberg \& Ployhart) and human capital resources diminish. The performance demands imposed on the team, however, often remain relatively unchanged, making it more difficult to meet these demands given limited team resources (Funke, Knott, Salas, Pavlas, \& Strang, 2012; Reilly et al., 2013). When confronted with increased demands, teams may respond by altering their performance and coordination strategy (Funke et al.), which, in turn, makes task conflicts more likely. At the same time, the outflow of human capital resources weakens team members' capacity for training each other (Reilly et al.), making it even more difficult to prevent misunderstandings and task conflicts in teams.

Second, collective turnover complicates coordination in teams (George \& Bettenhausen, 1990; Kozlowski \& Ilgen, 2006; Lepak, Liao, Chung, \& Harden, 2006). Team turnover often makes the reorganization of work within teams necessary (Van der Vegt et al., 2010; Wittenbaum et al., 1998). As team members often hold different roles and functions in a team and rely on different kinds of human capital for effective task accomplishment (Kozlowski, Gully, Nason, \& Smith, 1999), this reassignment of roles and redistribution of tasks is anything but trivial; when employees leave a team, the team may experience task conflicts due to the heightened need to redefine roles, task distribution, and work routines. This is especially likely when team members are interdependent (Hale, Ployhart, \& Shepherd, in press; Shaw, Duffy, et al., 2005), as, for example, is the case with health-care teams (Gibson, 1999; Wade, 1999).

It is important to highlight that we consider both team turnover and task conflict as constructs that change over time. There is a growing recognition among scholars that time has been neglected in organization research (Ployhart, Holtz, \& Bliese, 2002; Roe, 2008; Sonnentag, 2012). Although research has paid some attention to the dynamics in team functioning, such as team confidence (Goncalo, Polman, \& Maslach, 2010), team trust (Drescher, Korsgaard, Welpe, Picot, \& Wigand, 2014), and team performance (e.g., Lorinkova, Pearsall, \& Sims, 2013; for reviews, see Cronin, Weingart, \& Todorova, 2011; Humphrey \& Aime, 
2014; Roe, Gockel, \& Meyer, 2012), team turnover and team conflict research has remained rather static in its focus (e.g., see Hausknecht \& Trevor, 2011) and has rarely taken a dynamic perspective.

Possibly, this is because temporal research on team turnover is difficult to conduct because of a lack of guiding theory and methodologies and the complexity of the studied phenomenon (Roe, 2008). For instance, it is not obvious when and how often team turnover and related phenomena, such as team effectiveness, should be measured (see Mitchell \& James, 2001). Although one may want to measure team turnover (and related phenomena) as often as possible (ideally at every occurrence), such high-density assessment of organizational phenomena is often unfeasible from a practical standpoint. Another conceptual issue in longitudinal research on team turnover is the meaning associated with time, which may trigger different associations in the minds of researchers and practitioners. As our primary interest is in investigating changes in teams over time, we consider time to imply the development or progression of teams over a certain period of time. Specifically, we think of time as team progression (or team development), consistent with Raes, Heijltjes, Glunk, and Roe (2006). We follow teams across a multiyear period, not knowing when these teams emerged or when they will cease to exist.

Taken together, we hypothesize a relationship between team turnover (i.e., a time-varying predictor) and changes in task conflict. In building on CET theory (Nyberg \& Ployhart, 2013), we have argued that team turnover requires reassignment and readjustment of team roles, responsibilities, and task strategy, all of which may yield increases in task conflict within teams. We expect the effects of team turnover to be relatively long lasting and, thus, to accumulate over time. To the extent that this holds true, we would expect to find task conflict to increase over time in response to team turnover. This argument is consistent with empirical findings in the turnover literature (Hale et al., in press). Hale et al., in their study of 524 branches of a U.S. bank, found that it took these units months to recover (in terms of unit-level sales performance) from an employee leaving the unit. More specifically, Hale et al. state that "we find it will take 10 to 11 months to recover from an employee turnover event" (36). In line with these findings showing that the effects of team turnover are not transient but rather long term, the following relationship is proposed:

Hypothesis 1: Team turnover associates positively with an increase in task conflict.

\section{The Moderating Role of Organizational Tenure in the Team}

CET theory suggests that human capital resources and collective turnover jointly affect team performance (Nyberg \& Ployhart, 2013). Human capital resource describes an intangible unit-level construct emerging from individuals' KSAOs (Nyberg \& Ployhart; for details on the emergence of human capital resource, see Ployhart \& Moliterno, 2011). Human capital resource has been operationalized, for example, as tenure, experience, and education, with tenure and experience (which is a kind of tenure) being the most commonly used measures (Nyberg, Moliterno, Hale, \& Lepak, 2014). Tenure, or more specifically, organizational tenure, indicates the time that an individual has spent with an organization (Steffens, Shemla, Wegge, \& Diestel, 2014) or the length of employment within an organization (Ng \& Feldman, 2010). When aggregated to the team level, organizational tenure 
describes the average work experience and job-related knowledge of the members of that team (Ng \& Feldman). Such team-level organizational tenure is different from team tenure; team tenure describes the time that individuals have been members of the same team and serves as a proxy for social cohesion (Bell, Villado, Lukasik, Belau, \& Briggs, 2011; Michel \& Hambrick, 1992).

It is also important to distinguish between human capital resources, such as team organizational tenure, and team turnover. Although both human capital resources and team turnover share similarities, they are profoundly distinct (Nyberg \& Ployhart, 2013). Both human capital resources and team turnover emerge at the unit level, include qualitative components, and fluctuate over time (Nyberg \& Ployhart). However, their strategic value is fundamentally different: Organizations benefit from accumulating human capital resources, and they manage them strategically; team turnover, instead, typically has little strategic value, and organizations try to limit its negative consequences. Another important difference is that team turnover captures the KSAOs of team members who have left, whereas human capital resources, such as team organizational tenure, describe human resources that remain within the team (for other differences, see Nyberg \& Ployhart). In conclusion, there are "profound conceptual differences between collective turnover and human capital resources" (Nyberg \& Ployhart: 114).

Why does organizational tenure represent an important human capital resource? According to human capital resources theory (Becker, 1964), longer-tenured employees perform better because they have accumulated more job-related knowledge. Specifically, longer-tenured employees have greater organization-specific knowledge, including information about the functioning of the organization and its strategic direction, policy, rules, culture, and stakeholders (e.g., clients; Ng \& Feldman, 2010). Longer-tenured employees also have a better understanding of the organization's expectations of employees' roles and responsibilities (Chatman, 1989; Steffens et al., 2014) and tend to perform more effectively (Ng \& Feldman). Consistent with these individual-level arguments and based upon CET theory (Nyberg \& Ployhart, 2013), our expectation is that team organizational tenure attenuates the negative effects of team turnover (in terms of task conflict).

The higher the level of organizational tenure within a team, the more organization-specific experience and knowledge the team possesses, which, in turn, helps the team operate more effectively within an organization (Bell et al., 2011; Steffens et al., 2014). Work teams with high organizational tenure may know how to avoid or overcome obstacles to performance better (Steffens et al.) and how to access limited organizational resources, such as money, equipment, or infrastructure (Bell et al.; Ashforth, Joshi, Anand, \& O’Leary-Kelly, 2013).

For instance, teams with longer-tenured members may know how to persuade upper management to support the team because they have intimate knowledge of the organization (Ashforth et al., 2013). Such knowledge seems especially critical in times when teams need to cope with team turnover and the associated increase in workload demands. By obtaining organizational support and securing resources, teams with high organizational tenure are in a better position to respond to the increases in workload demands (compared to teams with low organizational tenure). Similarly, teams with high levels of organizational tenure, more than less experienced teams, may also know how to limit the potential for task conflict when redistributing roles and readjusting team goals, for instance, by excluding team goals that do 
not fit the strategic direction of the organization. To the extent that teams lack experienced members, teams may not be sufficiently aware of management expectations and may develop team goals that conflict with organizational goals (see Ancona, 1990).

Empirical research into how team-level organizational tenure would moderate the negative implications of team turnover is largely absent. To the best of our knowledge, only one study by Hausknecht et al. (2009) investigated how newcomer concentration (i.e., the proportion of newcomers in a team) exacerbates the influence that team turnover has on perceived service quality. The results of that study on 75 work units in the service industry suggest team turnover associates more negatively with perceived service quality in teams with higher newcomer concentration, providing some indirect support for the effects that we predict.

To conclude, we expect teams to cope better with team turnover the higher their organizational tenure is because these teams are more likely to get access to limited resources and because they know how to adapt their team strategy (as a response to increases in workload) in such ways that team goals are consistent with the overall organizational strategy, and, thus, viable. We argue that a high level of organizational tenure in the team buffers the negative effects of team turnover on team functioning; team turnover, therefore, should be associated less with increases in task conflict. Consequently, we investigate how a team's organizational tenure moderates the influence that team turnover has on changes in task conflict and hypothesize:

Hypothesis 2: Team-level organizational tenure moderates the association of team turnover and task conflict changes: The lower the organizational tenure in the team, the more likely it is that team turnover positively associates with an increase in task conflict.

\section{Method}

\section{Work Context}

Data were collected from a Dutch health-care organization with around 1,000 employees. The organization provides assistance to mentally and physically challenged clients and covers a range of nonmedical services in order to assist their clients. The clients live and/or spend time during the day in care facilities owned by the health-care organization. The services provided focus on facilitating self-care and include assistance in the areas of work, living, household tasks, dressing, hygiene assistance, and leisure time. Employees providing these services work together in ongoing teams of which the size varies. Team members are dependent on each other as they are jointly responsible for client assistance, use consensus in decision making, and draw from a shared pool of limited resources (e.g., expensive medical equipment, such as hydraulic patient lifts). Employee performance is evaluated at the team level by the health-care organization, which further increases team interdependence. Team leaders may be responsible for multiple teams, but they are not directly involved in performing client care. Hence, teams have a relatively high degree of decision-making freedom, for example, regarding work processes. Team conflicts are likely to occur, as team members interact regularly and because of the stressful nature of the work itself.

\section{Design and Procedure}

Data were collected at five different points in time by means of online questionnaires. The online questionnaires were available to all employees for 2 weeks. The actual dates at which 
Figure 1

Timeline

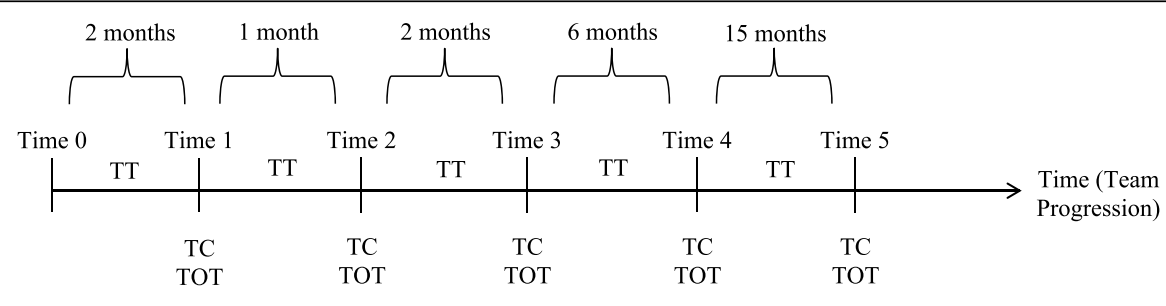

Note $: \mathrm{TT}=$ team turnover; $\mathrm{TC}=$ task conflict; $\mathrm{TOT}=$ team-level organizational tenure.

the data collections started were as follows: Time $1(\mathrm{~T} 1)=$ March 12, 2010; Time 2 (T2) = April 23, 2010; Time 3 (T3) = June 11, 2010; Time 4 (T4) = December 27, 2010; Time 5 (T5) $=$ March 16, 2012. The timeline in Figure 1 shows the setup of the data collection procedure.

Task conflict and organizational tenure in the team were measured at each of the five time points. Respondents were given a 2-week window to complete the survey, and although this might have introduced some noise in our data, we deemed this window necessary in order to allow for a higher response rate. Team turnover was calculated on the basis of monthly data on team membership of employees (these data were provided by the organization). This information allowed us to calculate the team turnover for each period between the five time points and for a 2-month period prior to T1. Thus, team turnover was measured in all five periods prior to task conflict and team-level organizational tenure. This is in line with recommendations from Nyberg and Ployhart (2013), who argued the case for a lagged assessment of the consequences of team turnover.

\section{Sample}

The health-care organization consisted of approximately 1,000 employees nested within 105 work units. After deleting teams with fewer than three members (Moreland, 2010) and omitting teams that did not provide direct care, and after excluding missing values, we were left with a final sample of 74 work units. The final sample at T1 consisted of 70 work units $(n=382)$; at T2, of 70 work units $(n=266)$; at T3, of 67 work units $(n=$ $238)$; at T4, of 67 work units $(n=148)$; and at T5, of 73 work units $(n=323)$. Instead of deleting teams for which a certain percentage of members had not responded, we included all available data in the analysis. This approach is in line with recent recommendations from Hirschfeld, Cole, Bernerth, and Rizzuto (2013) and from Maloney, Johnson, and Zellmer-Bruhn (2010). Maloney et al. concluded from a Monte Carlo simulation study that researchers should use all data available in order to increase the chance of detecting relationships actually existing. Although measurement reliability is reduced by including teams that had a low response rate in the analysis, this negative effect is outweighed by the positive effects of a larger sample size (Maloney et al.). The recommendation to "use all the data" (Maloney et al.: 296) holds also in extreme cases where only one team member represents an entire team.

On the basis of sample information at T1, the average team size was 10.9 team members $(S D=7.1)$ with a range of between 3 and 33 team members. Of the T1 respondents, $82 \%$ 
were female, and the average age of the individuals was 43.9 years old $(S D=11.3)$. The educational background of the individuals, based on the Dutch scholarly system, included $16.1 \%$ of employees with a general secondary education, $43.9 \%$ with a secondary professional education, $34.6 \%$ with a higher vocational education, and $5.4 \%$ with a university education. ${ }^{2}$ At $\mathrm{T} 5$, the average team size was 6.6 team members $(S D=4.0)$, ranging from 3 to 21 team members. Of the T5 respondents, $79 \%$ were female, and the average age of the individuals was 45.0 years old $(S D=6.8)$. The educational background of the individuals, based on the Dutch scholarly system, included $8.8 \%$ of employees with a general secondary education, $46.6 \%$ with a secondary professional education, $38.5 \%$ with a higher vocational education, and $6.1 \%$ with a university education.

\section{Measures}

Task conflict was measured by using a three-item scale from Janssen et al. (1999). This scale was based on the original one by Jehn (1995). Only minor changes of wording were necessary to adjust items to the context of this study and to comply with the wishes of the health-care organization involved in the data collection. Responses were given on a 5-point Likert-type scale ranging from 1 (strongly disagree) to 5 (strongly agree). The sample items used were "Team members regularly took divergent viewpoints on the issues involved," "Diverse perspectives on substantive issues were the rule rather than the exception," and "Team members had often very different ideas on substantive matters" (T1 $\alpha=.91$; T2 $\alpha=$ $.89 ; \mathrm{T} 3 \alpha=.80 ; \mathrm{T} 4 \alpha=.85$; T5 $\alpha=.69$ ). In order to meet the requirements imposed by a new management team that came into place after the fourth wave of data collection, we needed to rephrase one of the three depicted items: "Team members regularly took divergent viewpoints on the issues involved." The reverse-coded item used in the fifth wave was "Team members regularly took the same viewpoints on the issues involved."

Organizational tenure in the team was used to proxy human capital resources (see Nyberg et al., 2014) and calculated by taking the average across team members' organizational tenure (expressed in years of membership with the organization). As a result of sample restrictions, we were unable to obtain values for organizational tenure at T2 and T3. Therefore, we imputed the $\mathrm{T} 1$ values at $\mathrm{T} 2$ and $\mathrm{T} 3$.

For every time period, team turnover was measured by using an adjusted version of the separation rate (Price, 1977), taking into account the differences in quality of the leavers as called for by CET theory (Nyberg \& Ployhart, 2013). With our measure, we calculated team turnover on the basis of team composition information that we obtained from the health-care organization. Alongside providing information on team composition, we obtained data on the position and the contracted working hours of each employee. We integrated this information to construct a quality-adjusted team turnover measure.

First, we used the information available on position: The organization categorizes its employees according to formal education, proficiency, and experience into four different categories; this classification is typically used by organizations working with individuals who are mentally and physically disabled. In order to move up a category on the positional ladder, employees need to acquire additional skills, experience, and formal education. The higher the employees' category, the higher their salary will be. We therefore use salary (i.e., average salary of each category) as a proxy for employee quality. This is in line with CET theory suggestions that one may need to rely on proxy measures to capture quality in the 
turnover (Nyberg \& Ployhart, 2013). We linearly transformed the salary proxy in such a way that the value of 1 was assigned to the organization mean of salary. The average salary per category was represented as deviation from the sample mean in salary. Second, we multiplied the values obtained by the full-time equivalent (based on company data) of each leaver (e.g., 0.8 times for an employee working $80 \%$ ) and calculated a sum score across the members of each team. We divided the resulting team score by the average size of each team for each time period separately. We calculated the average size of each team by taking the mean over the number of employees that were part of a team at the very beginning and at the very end of a time period and refer to this as team size in the following. Taken together, we calculated team turnover per time period and team as follows: ${ }^{3}$

$$
\text { Quality }- \text { adjusted team turnover }=\frac{\sum(\text { salary proxy of leaver } * \text { full }- \text { time equivalent of leaver })}{\text { team size }}
$$

\section{Data Analysis Approach}

Aggregation statistics. To assess interrater agreement for task conflict within the teams, we calculated $r_{w g(j)}$ values from James, Demaree, and Wolf's (1984) agreement index for multi-item scales. The $r_{w g(j)}$ values obtained for task conflict ranged from .84 to .89 over the five time points, which is above the cutoff value of .70 (LeBreton \& Senter, 2008). Moreover, we calculated the intraclass correlation coefficient (ICC) values for task conflict in order to assess the interrater reliability. The ICC(1) values for task conflict ranged from .09 to .15 over the five time points, indicating a medium degree of variability due to team membership (Bliese \& Ployhart, 2002; LeBreton \& Senter). ICC(2) values for five time points ranged from .53 to .66 , indicating the reliability of group-mean values. We also calculated interrater agreement and reliability values for team-level organizational tenure and obtained ICC(1) values ranging from .06 to .14 and $\operatorname{ICC}(2)$ values ranging from .42 to .64. Although some ICC(2) values for both task conflict and team-level organizational tenure are below the cutoff value of .60 (Glick, 1985), we had sufficient theoretical and statistical justification to aggregate task conflict to the team level. We continued with the analysis because we obtained high interrater agreement values and demonstrated team-level effects (Chen \& Bliese, 2002). In addition, team conflict is considered a process that is basically meaningless at the individual level, which is why we used referent-shift items to study conflict at the team level (Chan, 1998; Klein, Conn, Smith, \& Sorra, 2001).

Random coefficient modeling framework. To analyze our longitudinal team-level data, we used random coefficient modeling (Bliese \& Ployhart, 2002; Singer \& Willett, 2003), largely following the five steps of growth modeling as described by Bliese and Ployhart. We first constructed a Level 1 model (i.e., within-team and between-team variability in task conflict) before introducing a set of predictors to explain interteam differences in task conflict (including differences at the start of the study and differences in how task conflict changed over time per team).

Unlike Bliese and Ployhart (2002), our model includes time-varying predictors. A timevarying predictor is a "variable whose values may differ over time" (Singer \& Willett, 2003: 159) or, put differently, a covariate that varies as a function of time (Curran, Obeidat, \& Losardo, 2010). In standard growth models, outcome measures are regressed on time-invariant 
predictors (i.e., Level 2 variables). Instead, we incorporated those time-varying measures (i.e., Level 1 variables) to explain variance in task conflict, that is, team turnover and team organizational tenure (McCoach \& Kaniskan, 2010; Singer \& Willett). More specifically, we built a model in which a repeatedly measured outcome variable (i.e., task conflict) was regressed on repeatedly measured values of team turnover and team organizational tenure (together with time and the interaction terms). Because we were interested in establishing change in task conflict and in studying how these changes related with team turnover, we needed to collect repeated observations over time (Ployhart \& Vandenberg, 2010). Specifically, there needs to be at least "three repeated observations (although more than three is better) on at least one of the substantive constructs of interest" (Ployhart \& Vandenberg: 97) in order to establish change. Our design satisfies this condition.

All models were estimated by using the nlme package in R (Version 2.15.0) to apply growth modeling according to the guidelines of Bliese and Ployhart (2002). For parameter estimation, we used restricted maximum likelihood. Thus, to test for differences in model fit when models did not differ in the fixed part, we relied on deviance statistics ( -2 log likelihood statistic; Hox, 2010).

\section{Results}

The descriptive statistics and zero-order correlations are depicted in Table 1. Mean values indicate that task conflict increased slightly over the five measurement points. Regarding the bivariate correlations, task conflict at T4 is positively correlated with team turnover in T3 and T5 (see Table 1). Bivariate correlations also show negative correlations between team turnover and team-level organizational tenure. However, such between-team results may obscure the actual within- and between-team variance of our longitudinal model, as Rogosa (1995) also convincingly demonstrated. Note that we did not expect all teams in our sample to experience increases in task conflict across the five measurement points.

\section{Modeling Changes in Task Conflict}

As a first step in the growth modeling process, we examined the properties of the dependent variable, task conflict (Bliese \& Ployhart, 2002). First, we calculated the ICC(1) of task conflict. ICC(1) values describe the amount of variance in task conflict due to between-team differences rather than within-team difference over time (see Hausknecht, Hiller, \& Vance, 2008). Estimating ICC(1) for task conflict by using team-level data signified multiple scores for each team because task conflict was sampled at five different time points for each team (Hausknecht et al.). ICC(1) for task conflict was .65, which indicates that $65 \%$ of the variance in task conflict can be attributed to between-team differences and that the remaining variance is due to within-team differences over time.

We coded time following best-practice recommendations in the literature (Ployhart \& Ward, 2011; Singer \& Willett, 2003). That is, to correct for the unequal spacing of the measurement points (see above), we coded the five measurement points not from 1 to 5 but as $0,1,3,9$, and 24 , respectively, because these values reflect the actual chronological distance between the measurement waves. Thereby, every 1-unit change in time represents a team's change in task conflict over a period of approximately 1 month (Singer \& Willett). If we had not recoded time in such ways, the values for time would have had little substantive meaning (Singer \& Willett). 


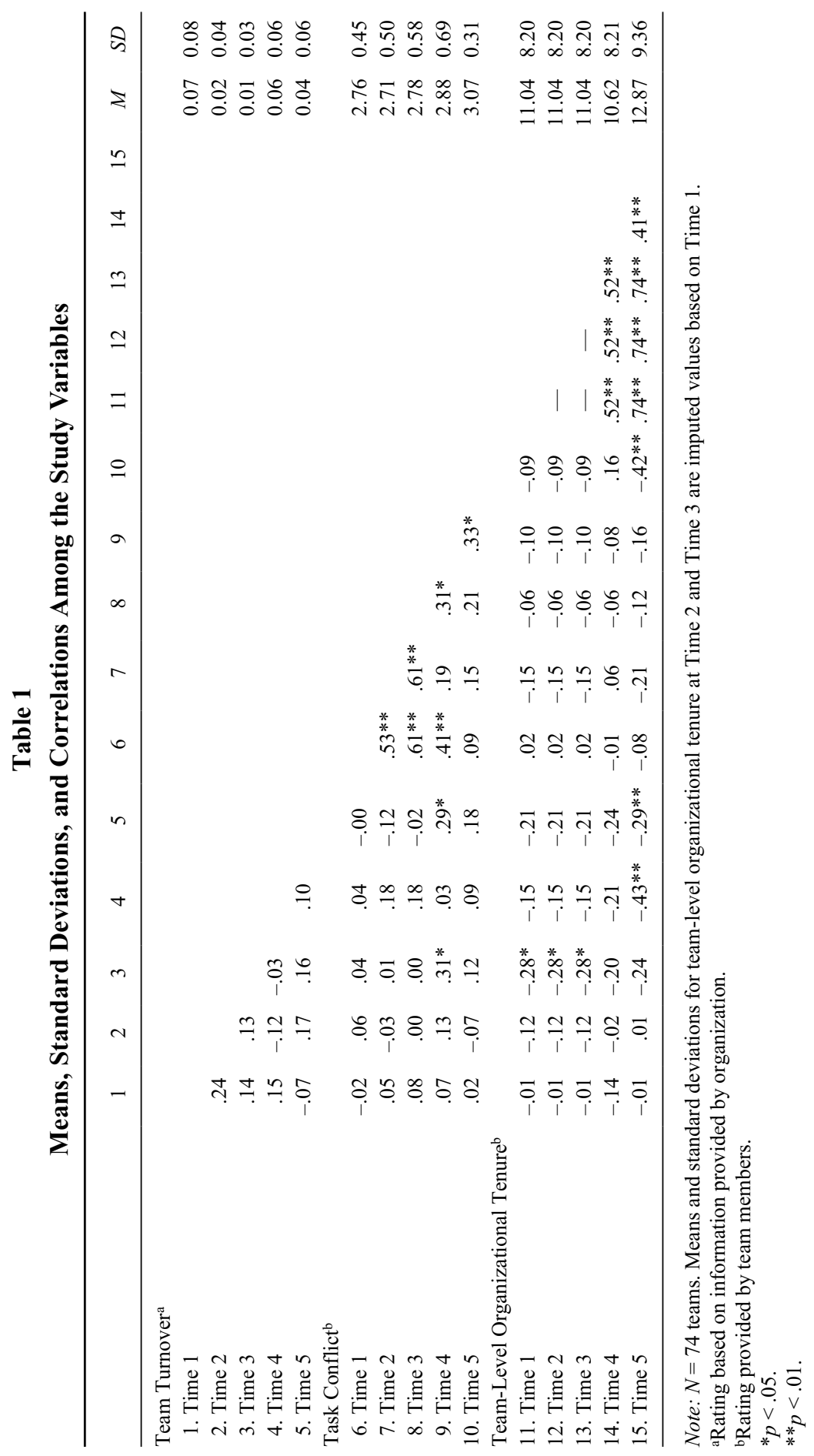


We then modeled the fixed relationship between time and task conflict, assessing linear and quadratic trends (Bliese \& Ployhart, 2002). Following the steps described by Bliese and Ployhart, we observed that time had only a linear relationship with task conflict as the quadratic trend showed no significant effect. ${ }^{4}$

As a next step in the model building process, we added a random-intercept term to test for between-team differences in initial levels of task conflict (i.e., differences at the start of the study). Looking at the $-2 \log$ likelihood difference test, we can see that the random-intercept model (see Table 2, Model 1) fitted the data significantly better than the fixed-intercept model $(\Delta-2 \log$ likelihood $=3.39, p<.01)$. We then tested for the possibility that teams differed not only in the amount of task conflict they experienced at the start of the study (i.e., random-intercept model) but also in the way that task conflict changed over time (i.e., random-slope model). Therefore, we added a linear effect for time as a random effect to our earlier random-intercept model. However, the results show that the model allowing for the slope of task conflict to vary across teams did not fit the empirical data better $(\Delta-2$ log likelihood $=1.87, p=.15)$.

The fact that we did not find significant slope variance may be due to the fact that tests for slope variance have low power generally, and scholars have recommended testing for hypothesized effects (e.g., cross-level interaction effects) "regardless of the significance of slope variance" (LaHuis \& Ferguson, 2009: 433). Evidence in line with this recommendation can be found, for example, in Murray, Holmes, Derrick, Harris, Griffin, and Pinkus (2013), who specified the lagged effect of time as being fixed rather than random. We therefore continued in our analysis with a linear random-intercept model. Assessing the appropriate error structure of the linear random-intercept model, we checked for both autocorrelation and heteroscedasticity. Further model comparisons (see Table 2) showed a significant improvement for the model that allows for autocorrelation $(\Delta-2 \log$ likelihood $=4.1745$, $p<.01)$ but not for the model that allows for changes in variances (heteroscedasticity). Consequently, the random-intercept model controlling for autocorrelation (Model 2) appears to fit the data best.

\section{Team Turnover as Predictor of Task Conflict Changes}

To test for the time-varying effects, we entered team turnover, team progression (time), and organizational tenure in the team into the model as time-varying predictors. Next, the interaction effects of team turnover, team progression (time), and team-level organizational tenure were entered into the model. Team-level organizational tenure was group-mean centered to facilitate interpretation (Singer \& Willett, 2003). Team turnover was not centered because Ployhart, Weekley, and Ramsey (2009) recommend that the turnover rate does not have to be centered as it can range only from 0 to 1 . Hence, 0 has a meaningful interpretation because it indicates that there is no turnover in the team.

Hypothesis 1 posited that the time-varying predictor of team turnover would be positively associated with changes in task conflict. Results in Table 2 (Model 4) show that the interaction effect of team turnover and team progression (time) on task conflict is insignificant, thus not supporting Hypothesis $1(b=0.05, S E=0.05)$. Although not hypothesized, it is interesting to note that the two-way interactions of team-level organizational tenure with time $(b=-0.00$, $S E=0.00)$ and team turnover with team-level organizational tenure $(b=-0.07, S E=0.10)$ were insignificant also (see Table 2, Model 4). 


\section{Table 2}

Results of Fitting Random Coefficient Models to Task Conflict

\begin{tabular}{|c|c|c|c|c|c|}
\hline Parameter & Model 1 & Model $2^{\mathrm{a}}$ & Model 3 & Model 4 & Model 5 \\
\hline \multicolumn{6}{|l|}{ Fixed effects } \\
\hline $\begin{array}{l}\text { Intercept (initial status } \\
\text { at Time 1) }\end{array}$ & $2.75(0.05)^{* *}$ & $2.75(0.05)^{* *}$ & $2.93(0.09)^{* *}$ & $2.89(0.12)^{* *}$ & $2.95(0.12)^{* *}$ \\
\hline Time (rate of change) & $0.01(0.00)^{* *}$ & $0.01(0.00)^{*}$ & $0.01(0.00)^{* *}$ & $0.01(0.01)$ & $0.01(0.01)$ \\
\hline \multicolumn{6}{|l|}{ Main effects } \\
\hline Team turnover & & & $-0.25(0.45)$ & $0.16(1.15)$ & $-1.66(1.44)$ \\
\hline $\begin{array}{l}\text { Team-level } \\
\text { organizational tenure }\end{array}$ & & & $-0.02(0.01)^{*}$ & $-0.01(0.01)$ & $-0.01(0.01)$ \\
\hline \multicolumn{6}{|l|}{ Two-way interactions } \\
\hline $\begin{array}{l}\text { Team Turnover } \times \\
\text { Time }\end{array}$ & & & & $0.05(0.05)$ & $0.32(0.14)^{*}$ \\
\hline $\begin{array}{l}\text { Team-Level } \\
\text { Organizational } \\
\text { Tenure } \times \text { Time }\end{array}$ & & & & $-0.00(0.00)$ & $0.00(0.00)$ \\
\hline $\begin{array}{l}\text { Team Turnover } \\
\times \text { Team-Level } \\
\text { Organizational } \\
\text { Tenure }\end{array}$ & & & & $-0.07(0.10)$ & $0.10(0.13)$ \\
\hline \multicolumn{6}{|l|}{ Three-way interaction } \\
\hline $\begin{array}{c}\text { Team Turnover } \\
\times \text { Team-Level } \\
\text { Organizational } \\
\text { Tenure } \times \text { Time }\end{array}$ & & & & & $-0.02(0.01)^{*}$ \\
\hline \multicolumn{6}{|l|}{$\begin{array}{l}\text { Random effects } \\
\text { (variance) }\end{array}$} \\
\hline $\begin{array}{l}\text { Level 1: Within-team } \\
\text { variance }\end{array}$ & .10 & .07 & .08 & .08 & .08 \\
\hline Level 2: In intercept & .18 & .21 & .20 & .20 & .19 \\
\hline \multicolumn{6}{|l|}{ Goodness of fit } \\
\hline$-2 \log$ likelihood & 226.54 & 222.37 & 213.78 & 212.91 & 210.61 \\
\hline$\Delta-2 \log$ likelihood & & $4.17 * *$ & $8.95 * *$ & 0.87 & $3.17 * *$ \\
\hline $\begin{array}{l}\text { Akaike information } \\
\text { criterion }\end{array}$ & 461.08 & 454.73 & 441.57 & 445.82 & 443.23 \\
\hline $\begin{array}{l}\text { Bayesian information } \\
\text { criterion }\end{array}$ & 476.14 & 473.56 & 467.75 & 483.23 & 484.37 \\
\hline
\end{tabular}

Note: $N=74$ teams. Unless otherwise indicated, the table provides unstandardized coefficients, with standard errors in parentheses, for each measure.

aModel 2 corrected for autocorrelation.

$* p<.05$.

$* * p<.01$.

\section{Do Team Turnover and Team-Level Organizational Tenure Predict Task Conflict Changes?}

Hypothesis 2 suggested a three-way interaction of team turnover, team progression (time), and team-level organizational tenure, such that the higher the organizational tenure in the team, the less likely it would be that team turnover associated with changes in task conflict. 
Results from the three-way interaction term shown in Table 2 (Model 5) provide support for this hypothesis $(b=-0.02, S E=0.01, p<.05)$. We conducted a post hoc analysis to determine whether we would have obtained substantively different results by using a traditional separation rate. This analysis produced only slightly different results (compared to our main analysis), and we also found a significant three-way interaction effect $(b=-0.013, S E=0.006$, $p<.05)$. We return to this in the Discussion section.

To advance further interpretations, we plotted the three-way interaction (including the quality-adjusted measure of team turnover) by using an online computational tool from Preacher, Curran, and Bauer (2006). We used this tool as recommended by K. J. Preacher (personal communication, April 18, 2013), which resulted in the final three-way interaction plot (see Figure 2). Integrating both outputs and running the combined code produces the final three-way interaction plot (see Figure 2). Figure 2 serves as an illustration of these timevarying effects in that it displays task conflict changes as a function of different combinations of team turnover and team organizational tenure. Specifically, Figure 2 shows how task conflict changes over time for high/low team turnover and high/low team organizational tenure at both $1 S D$ below and $1 S D$ above the mean. Still, readers should keep in mind that such interaction plots are limited in that they do not allow visualizing the fact that team turnover and team organizational tenure also change over time.

Figure 2 shows how task conflict changed over the five measurement points depending upon the given level of team turnover and team-level organizational tenure. Additionally, we conducted simple-slope analyses (see Preacher et al., 2006) and calculated slope difference tests (Dawson, 2014; Dawson \& Richter, 2006). Note that the results from slope difference tests should still be interpreted with caution because test power is restricted unless the sample size is considerably large (see Meier, Semmer, Elfering, \& Jacobshagen, 2008).

We found that for teams with low team turnover, task conflict remained stable over time when team-level organizational tenure was low $(b=-0.00, S E=0.01, p=.75)$, but it seemed to increase somewhat when team-level organizational tenure was high $(b=0.01, S E=0.01$, $p=.08$ ). More importantly, though, we found that for teams with high team turnover, task conflict significantly increased over time when team-level organizational tenure was low $(b=0.02, S E=0.01, p=.00)$, but it did not increase when team-level organizational tenure was high $(b=0.00, S E=0.01, p=.79)$. As shown in Table 3 , the difference between these two slopes for high team turnover was marginally significant $(t=-1.84, p=.07)$. Taken together, these results provide support for Hypothesis 2 .

\section{Discussion}

This study's purpose was twofold. One purpose was to extend the knowledge on team turnover: We examined team turnover (measured as a quality-adjusted version of the commonly used separation rate measure) across five measurement points and studied its association with task conflict changes. Against what we hypothesized, we did not find an overall association between team turnover - which we conceptualized as a time-varying predictor-and task conflict changes. Another purpose was to enhance our understanding of how to mitigate the association between team turnover and task conflict changes. We proposed that in teams with high organizational tenure, team turnover would associate less with increases in task conflict. Consistent with expectations, our results showed that team-level organizational tenure served as a buffer against the negative effects (i.e., increase in task conflict) of team turnover. 
Figure 2

Three-Way Interaction Plot

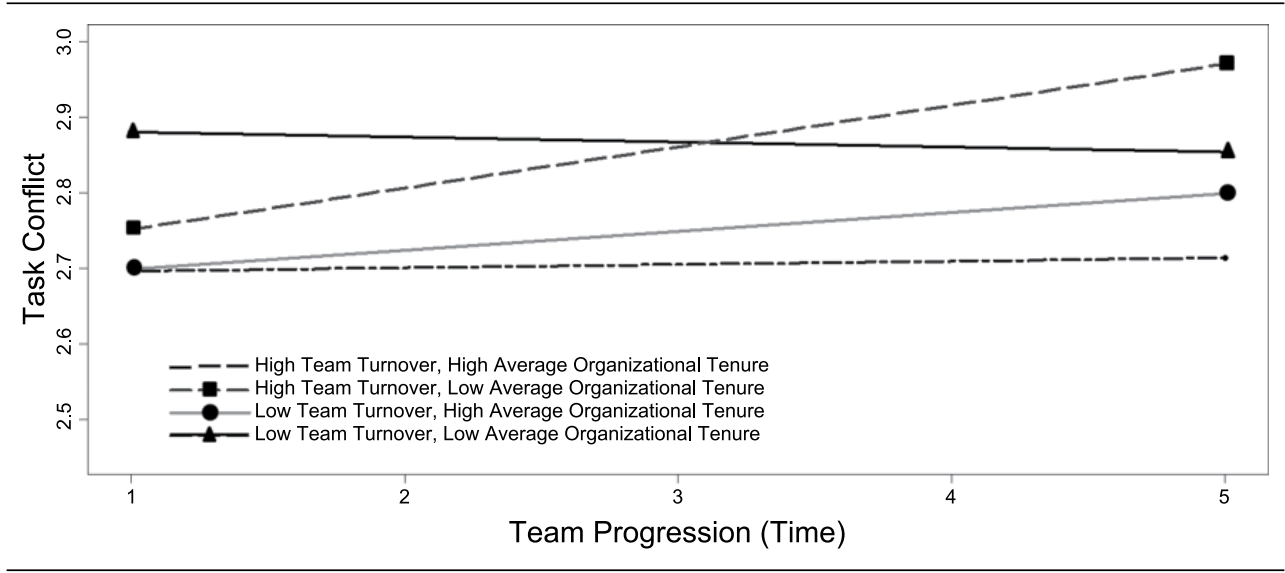

Note: Time intervals are unequal (for more details, see Figure 1). Low $=1 S D$ below the mean; high $=1 S D$ above the mean.

\section{Theoretical Contributions}

Hausknecht and Trevor (2011) called for further research into team-level turnover processes and moderators of the turnover-outcome relationship. The present study addresses this call and contributes to a small but growing body of research into the contextual factors that render the effects of team turnover less negative (see Hausknecht \& Trevor). That we find organizational tenure in teams to reduce the risk that, over time, task conflict increases in response to team turnover speaks to the important but understudied moderating role of team-level organizational tenure. Our finding appears to be consistent with Hausknecht et al. (2009), who found the negative relationship between team turnover and perceived service quality to be stronger in teams with higher newcomer concentration (and, thus, lower organizational tenure). We contribute to and go beyond these findings by showing that the buffering effects of team-level organizational tenure also hold when assessed across time and when focusing on one of the most prevalent team processes, that is, task conflict.

Our findings appear to be inconsistent with Hirst (2009), who found turnover in R\&D teams to lead to less open discussion and lower team performance for longer-tenured teams. Aside from that we investigated health-care teams and not $R \& D$ teams, this difference in findings may well be due to the fact that Hirst assessed team tenure, whereas we studied (teamlevel) organizational tenure. As team tenure increases, social cohesion increases and members develop common perspectives and shared mental models. The more uniform these cognitive structures become, the more difficult it might be to integrate the novel insights that newcomers bring to the team, which may hamper open communication and team performance. Team-level organizational tenure, instead, provides a reservoir of organization-specific knowledge; such knowledge helps teams to access limited organizational resources and to make changes that align with organizational goals, and the more of this kind of knowledge a team possesses, the easier it is for the team to cope with team turnover. 
Table 3

Results of Slope Difference Test for Three-Way Interactions

\begin{tabular}{lcc}
\hline Pair of slopes & $\begin{array}{c}t \text { value for slope } \\
\text { difference }\end{array}$ & $\begin{array}{c}p \text { value for } \\
\text { slope difference }\end{array}$ \\
\hline 1 and 2 & $-1.84 \dagger$ & .07 \\
1 and 3 & -0.88 & .38 \\
1 and 4 & 0.44 & .66 \\
2 and 3 & 1.39 & .17 \\
2 and 4 & $2.39^{*}$ & .02 \\
3 and 4 & 1.28 & .20 \\
\hline
\end{tabular}

Note: 1 = high team turnover, high team-level organizational tenure; $2=$ high team turnover, low team-level organizational tenure; 3 = low team turnover, high team-level organizational tenure; $4=$ low team turnover, low team-level organizational tenure.

${ }^{\dagger} p<.10$.

$* p<.05$.

Unlike Van der Vegt et al. (2010), we did not find team turnover to have a negative main effect. This may be due to the fact that we were interested in task conflict as an outcome measure, whereas Van der Vegt et al. focused on social integration (amongst other things). Discrepancies in findings may also have to do with analytical differences: Van der Vegt et al. used a time-lagged analysis to assess the effects of team turnover (measured as separation rate), whereas we used growth modeling analyses to predict changes in task conflict by means of a time-varying measure of team turnover (measured as quality-adjusted team turnover). Notwithstanding these conceptual and methodological differences between our study and the Van der Vegt et al. study, the nonsignificant longitudinal main effect in our study remains difficult to explain. Possibly, the teams in our study reacted to team turnover by increasing team effort toward accomplishing goals (e.g., Pearsall, Ellis, \& Stein, 2009). If collective motivation in teams did indeed increase over time, this increase in motivation might have compensated for the negative effects associated with the depletion of human capital resources, thereby producing an overall longitudinal null effect in terms of task conflict changes. Although speculative at this point, future research into how motivational (e.g., collective effort) and behavioral (e.g., team coordination) consequences of team turnover are at play together seems important.

Our results also provide empirical support for some key tenets of CET theory; CET theory states that turnover rates are part of a dynamic system, which implies that the effects of turnover rates change over time (Nyberg \& Ployhart, 2013). Given that we found team turnover to influence the functioning of teams over time-if only contingent upon the degree of teamlevel organizational tenure - our study provides some indirect support for this view. More importantly still, we provide statistical support for the interactive effect between human capital resources (e.g., team organizational tenure) and collective turnover (e.g., team turnover). Thus, our findings further enhance confidence in CET theory and respond to related calls to study the effects of human capital and turnover jointly and over time (Nyberg \& Ployhart). We thus believe that our findings provide an important stepping-stone for future research to more fully comprehend the effects of team turnover as they play out over time.

Additionally, in this study we introduced a new and alternative way to measure turnover in teams, which differs from the widely used separation rate (i.e., total number of leavers 
divided by the average team size; Price, 1977). Our measure of team turnover includes an indicator of quality in team turnover in terms of human capital resource depletion. In developing and using that quality-adjusted measure, we respond to Allen et al. (2010), who argued that the separation rate is not a sufficient indicator to show the extent to which turnover is functional or dysfunctional. Although we would have found similar results - similar to those reported in this study - when using the separation rate, we believe that from a theoretical point of view, it is preferable to account for the quality of leavers because this matches with CET theory (Nyberg \& Ployhart, 2013) and other more recent theorizing on team turnover (Hausknecht \& Trevor, 2011; Shaw, 2011).

In testing the relationship of team turnover and task conflict in a longitudinal fashion (i.e., by testing a five-wave growth model of task conflict changes regressed upon team turnover), we also address methodological calls in the team turnover literature. On the basis of a review of methodological design choices made in the past by turnover scholars, Allen et al. (2014) concluded that future research may benefit from relying more strongly on underutilized analytical techniques, such as random growth modeling. The use of such advanced techniques, according to Allen et al., may help to renew our thinking about team turnover as a dynamic construct that varies across time. Further research, however, into the exact pattern of changes in team turnover over time seems imperative.

\section{Practical Implications}

Team turnover is common in organizations and, as such, our findings should hold interesting insights for practice. First, the fact that team-level organizational tenure alleviates some of the negative implications of team turnover suggests that leaders should focus their attention on teams that lack experienced members. The less rich a team is in organization-specific experience and knowledge, the more important it becomes for leaders to support those teams in times of team turnover. Teams with higher organizational tenure, instead, may need less leader attention. Obviously, such a differential approach is suggested on the basis of the assumption that leaders have the means (e.g., team-level data) to tell apart experienced teams (i.e., high organizational tenure) from inexperienced teams (i.e., low organizational tenure) in order to allocate resources accordingly. Leaders may also need to sensitize especially those teams with low organizational tenure for the potentially harmful effects of team turnover.

Second, organizations nowadays tend to adopt accepted practices that are in line with more flexible ways of working (Beck, 2000). One of the features of these new work practices is that employees no longer have fixed work places and that they are moved from team to team more frequently. This kind of team turnover needs to be handled carefully in light of the findings of this study. Our results show the potential pitfalls of adhering to these new work practices, as team turnover can offset the initial benefits of these new work practices. Managers who intend to adopt flexible work practices need to keep in mind their potentially negative consequences for the functioning of teams (e.g., task conflicts) and, thus, compose teams in such a way that they have sufficient organizational experience from which to draw.

\section{Limitations and Future Research}

Our study has some limitations. The first limitation is that we cannot completely rule out reverse causality. Even though we measured our independent variable (i.e., team turnover) at 
an earlier time point than the other main model variables, the possibility remains that task conflicts may also have delayed effects on team turnover (i.e., task conflict measured at T1 may still have implications for team turnover measured at T2). To the best of our knowledge, no research has yet assessed this possibility. Thus, future longitudinal research seems necessary in order to advance our understanding on how and when team turnover influences task conflict changes. Along these lines, it would also be important to understand better how long it takes for team turnover to manifest in task conflict changes. Said differently, we know too little still about the time lag between team turnover and task conflict changes (see Mitchell \& James, 2001), something that scholars may want to investigate in the future.

Second, we accounted for the possibility that team turnover varies over time by conceptualizing team turnover as a time-varying predictor. Still, we did not isolate the effects that changes in team turnover may have on task conflict changes. For future research, it would be interesting to ascertain whether changes of team turnover (e.g., increase in team turnover over time) would matter in terms of task conflict changes (see Call et al., 2015). Such changeon-change relationships, however, are best tested by means of latent growth modeling approaches that afford a somewhat larger sample size, that is, sample sizes close to at least 100 teams per time point (Curran et al., 2010).

Third, because of restrictions from the sample organization, we were unable to collect data on team-level organizational tenure for the measurement points T2 and T3. Given that only 4 and 8 weeks passed between Waves 1 and 2 and Waves 2 and 3, respectively, we expected team-level organizational tenure to remain somewhat stable and imputed the T1 values at T2 and T3. Related to this, we collected data over a 2-week window for each time point, and this could be a potential source of "noise" in the data. Although we do not believe this to have influenced our results substantially, future research may need to obtain data over shorter time windows.

Fourth, our quality-adjusted metric of team turnover captures team turnover more realistically than turnover rates that focus only on quantity; still, further refinement of our measure would appear prudent. Using only salary as a proxy for quality in combination with working hours may, therefore, be only a first step towards constructing an optimal measurement tool, and future research should try to refine existing team turnover measures further. Moreover, other team characteristics (e.g., newcomer and remaining members' proficiencies) not included in our quality-adjusted metric are worthwhile considering for future research as they may also be important for understanding team turnover and its implications more fully (Hausknecht \& Holwerda, 2013). More specifically, future research should focus on the relative amount of human capital resources that is lost by taking into account both the human capital resources of leavers and those who stay in each team, for instance, by considering KSAOs (or proxies thereof) in both the numerator and the denominator of the turnover metric. Another approach would be to test for moderation between the separation rate (Price, 1977) and possible quality moderators (e.g., KSAOs or team competencies), thereby breaking up the turnover measure and assessing the quantitative and qualitative effects separately.

Fifth, it seems necessary to assess how far our findings generalize to other work contexts. In the context of health-care teams, longer team-level organizational tenure equates to greater KSAOs, but this is not necessarily the case for other professions and industries. Possibly, team organizational tenure provides fewer advantages for teams that work on narrow routine 
jobs that require little training. This is because routine and narrow jobs may provide relatively few opportunities for learning new skills, and acquiring such skills may be less relevant for performance compared to more varied and complex jobs. Future research seems necessary in order to assess how far our findings also hold in low-skilled professions.

Finally, future research should try to identify a larger set of team- and organization-level factors that may help attenuate the negative implications of team turnover. For instance, functional leadership theory suggests that it is the task of the team leader "to do, or get done, whatever is not being adequately handled for group needs" (McGrath, 1962: 5, as cited in Hackman \& Walton, 1986). Thus, to the extent that team leaders help teams solve those problems that arise when members leave a team, the negative implications of team turnover should be reduced. Hence, by integrating insights from team and leadership research, team turnover researchers may identify new means that help teams deal with team turnover. In addition, and consistent with CET theory, environmental complexity could be an important moderator (Nyberg \& Ployhart, 2013). Environmental complexity describes the "nature of interconnections and interdependence required by unit task demands" (Nyberg \& Ployhart: 120). The higher the environmental complexity, the stronger the need for synchronized coordination, timely information exchange, and tight social networks, which, in turn, may imply that team turnover is more likely to go hand in hand with task conflict when environmental complexity is high but not when it is low. To test such propositions, scholars would need to collect data across industries and jobs that vary in environmental complexity. Although these data may be difficult to collect over time, the payoffs may be immense, and we encourage future longitudinal multi-industry research into the effects of team turnover.

\section{Conclusion}

This research adds to a growing number of studies that are exploring turnover at the team level (Hausknecht \& Trevor, 2011; Shaw, 2011). Using a quality-adjusted team turnover measure, we assessed the link between team turnover-repeatedly measured over five time points - and changes in task conflict. Although no direct effect existed, we found a significant interaction effect: The higher the team-level organizational tenure, the less likely it was for team turnover to go hand in hand with increases in task conflict. Health-care organizations and their work teams may benefit from our findings by becoming aware of how organizational tenure in teams helps in dealing with the negative implications of team turnover. We believe that these results may have profound implications for how to assemble teams and, also, how to support teams that need to cope with the human capital resources drain that typically associates with team turnover.

\section{Notes}

1. The terms team turnover and collective turnover can be used interchangeably as both refer to an aggregate level of turnover. Given that the unit of analysis in our study is teams, we use only the term team turnover throughout this paper.

2. Numbers are based on valid responses in the sample.

3. The metric aligns with recommendations from Hausknecht and Trevor (2011) and suggestions by Nyberg and Ployhart (2013: 126).

4. Results can be obtained from the first author upon request. 


\section{References}

Akgün, A. E., \& Lynn, G. S. 2002. Antecedents and consequences of team stability on new product development performance. Journal of Engineering and Technology Management, 19: 263-286.

Allen, D. G., Bryant, P. C., \& Vardaman, J. M. 2010. Retaining talent: Replacing misconceptions with evidencebased strategies. Academy of Management Perspectives, 24(2): 48-64.

Allen, D. G., Hancock, J. I., Vardaman, J. M., \& McKee, D. N. 2014. Analytical mindsets in turnover research. Journal of Organizational Behavior, 35: S61-S86.

Ancona, D. G. 1990. Outward bound: Strategies for team survival in an organization. Academy of Management Journal, 33: 334-365.

Arrow, H., \& McGrath, J. E. 1993. Membership matters: How member change and continuity affect small group structure, process, and performance. Small Group Research, 24: 334-361.

Ashforth, B. E., Joshi, M., Anand, V., \& O'Leary-Kelly, A. M. 2013. Extending the expanded model of organizational identification to occupations. Journal of Applied Social Psychology, 43: 2426-2448.

Beck, U. 2000. The brave new world of work. Cambridge, MA: Polity Press.

Becker, G. 1964. Human capital: A theoretical and empirical analysis, with special reference to education. New York: Comlumbia University Press.

Bell, S. T., Villado, A. J., Lukasik, M. A., Belau, L., \& Briggs, A. L. 2011. Getting specific about demographic diversity variable and team performance relationships: A meta-analysis. Journal of Management, 37: 709-743.

Bliese, P. D., \& Ployhart, R. E. 2002. Growth modeling using random coefficient models: Model building, testing, and illustrations. Organizational Research Methods, 5: 362-387.

Bradley, J., White, B. J., \& Mennecke, B. E. 2003. Teams and tasks: A temporal framework for the effects of interpersonal interventions on team performance. Small Group Research, 34: 353-387.

Call, M., Nyberg, A., Ployhart, R., \& Weekley, J. 2015. The dynamic nature of turnover and unit performance: The impact of time, quality, and replacements. Academy of Management Journal, 58: 1208-1232.

Chan, D. 1998. Functional relations among constructs in the same content domain at different levels of analysis: A typology of composition models. Journal of Applied Psychology, 83: 234-246.

Chatman, J. A. 1989. Improving interactional organizational research: A model of person-organization fit. Academy of Management Review, 14: 333-349.

Chen, G., \& Bliese, P. D. 2002. The role of different levels of leadership in predicting self- and collective efficacy: Evidence for discontinuity. Journal of Applied Psychology, 87: 549-556.

Cronin, M. A., Weingart, L. R., \& Todorova, G. 2011. Dynamics in groups: Are we there yet? The Academy of Management Annals, 5: 571-612.

Curran, P. J., Obeidat, K., \& Losardo, D. 2010. Twelve frequently asked questions about growth curve modeling. Journal of Cognition and Development, 11: 121-136.

Dawson, J. F. 2014. Moderation in management research: What, why, when, and how. Journal of Business and Psychology, 29: 1-19.

Dawson, J. F., \& Richter, A. W. 2006. Probing three-way interactions in moderated multiple regression: Development and application of a slope difference test. Journal of Applied Psychology, 91: 917-926.

Drescher, M. A., Korsgaard, M. A., Welpe, I. M., Picot, A., \& Wigand, R. T. 2014. The dynamics of shared leadership: Building trust and enhancing performance. Journal of Applied Psychology, 99: 771-783.

Funke, G. J., Knott, B. A., Salas, E., Pavlas, D., \& Strang, A. J. 2012. Conceptualization and measurement of team workload: A critical need. Human Factors, 54: 36-51.

George, J. M., \& Bettenhausen, K. 1990. Understanding prosocial behavior, sales performance, and turnover: A group-level analysis in a service context. Journal of Applied Psychology, 75: 698-709.

Gersick, C. J. 1988. Time and transition in work teams: Toward a new model of group development. Academy of Management Journal, 31: 9-41.

Gibson, C. B. 1999. Do they do what they believe they can? Group efficacy and group effectiveness across tasks and cultures. Academy of Management Journal, 42: 138-152.

Glick, W. H. 1985. Conceptualizing and measuring organizational and psychological climate: Pitfalls in multilevel research. Academy of Management Review, 10: 601-616.

Goncalo, J. A., Polman, E., \& Maslach, C. 2010. Can confidence come too soon? Collective efficacy, conflict and group performance over time. Organizational Behavior and Human Decision Processes, 113: 13-24.

Greer, L. L., Jehn, K. A., \& Mannix, E. A. 2008. Conflict transformation: A longitudinal investigation of the relationships between different types of intragroup conflict and the moderating role of conflict resolution. Small Group Research, 39: 278-302. 
Guetzkow, H., \& Gyr, J. 1954. An analysis of conflict in decision-making groups. Human Relations, 7: $367-381$.

Hackman, J. R., \& Walton, R. E. 1986. Leading groups in organizations. In P. S. Goodman \& Associates (Eds.), Designing effective work groups: 72-119. San Francisco: Jossey-Bass

Hale, D., Ployhart, R., \& Shepherd, W. in press. A two-phase longitudinal model of a turnover event: Disruption, recovery rates, and moderators of collective performance. Academy of Management Journal. doi:10.5465/ amj.2013.0546

Hancock, J. I., Allen, D. G., Bosco, F. A., McDaniel, K. R., \& Pierce, C. A. 2013. Meta-analytic review of employee turnover as a predictor of firm performance. Journal of Management, 39: 573-603.

Hausknecht, J. P., Hiller, N. J., \& Vance, R. J. 2008. Work-unit absenteeism: Effects of satisfaction, commitment, labor market conditions, and time. Academy of Management Journal, 51: 1223-1245.

Hausknecht, J. P., \& Holwerda, J. A. 2013. When does employee turnover matter? Dynamic member configurations, productive capacity, and collective performance. Organization Science, 24: 210-225.

Hausknecht, J. P., \& Trevor, C. O. 2011. Collective turnover at the group, unit, and organizational levels: Evidence, issues, and implications. Journal of Management, 37: 352-388.

Hausknecht, J. P., Trevor, C. O., \& Howard, M. J. 2009. Unit-level voluntary turnover rates and customer service quality: Implications of group cohesiveness, newcomer concentration, and size. Journal of Applied Psychology, 94: 1068-1075.

Hirschfeld, R. R., Cole, M. S., Bernerth, J. B., \& Rizzuto, T. E. 2013. Voluntary survey completion among team members: Implications of noncompliance and missing data for multilevel research. Journal of Applied Psychology, 98: 454-468.

Hirst, G. 2009. Effects of membership change on open discussion and team performance: The moderating role of team tenure. European Journal of Work and Organizational Psychology, 18: 231-249.

Hox, J. J. 2010. Multilevel analysis: Techniques and applications. New York: Taylor \& Francis.

Humphrey, S. E., \& Aime, F. 2014. Team microdynamics: Toward an organizing approach to teamwork. The Academy of Management Annals, 8: 443-503.

James, L. R., Demaree, R. G., \& Wolf, G. 1984. Estimating within-group interrater reliability with and without response bias. Journal of Applied Psychology, 69: 85-98.

Janssen, O., Van De Vliert, E., \& Veenstra, C. 1999. How task and person conflict shape the role of positive interdependence in management teams. Journal of Management, 25: 117-141.

Jehn, K. A. 1995. A multimethod examination of the benefits and detriments of intragroup conflict. Administrative Science Quarterly, 40: 256-282.

Jehn, K. A., \& Mannix, E. A. 2001. The dynamic nature of conflict: A longitudinal study of intragroup conflict and group performance. Academy of Management Journal, 44: 238-251.

Kacmar, K. M., Andrews, M. C., Van Rooy, D. L., Steilberg, R. C., \& Cerrone, S. 2006. Sure everyone can be replaced . . . but at what cost? Turnover as a predictor of unit-level performance. Academy of Management Journal, 49: 133-144.

Klein, K. J., Conn, A. B., Smith, D. B., \& Sorra, J. S. 2001. Is everyone in agreement? An exploration of withingroup agreement in employee perceptions of the work environment. Journal of Applied Psychology, 86: 3-16.

Kozlowski, S. W., Gully, S. M., Nason, E. R., \& Smith, E. M. 1999. Developing adaptive teams: A theory of compilation and performance across levels and time. In D. R. Ilgen \& E. D. Pulakos (Eds.), The changing nature of performance: Implications for staffing, motivation, and development: 240-292. San Francisco: Jossey-Bass.

Kozlowski, S. W., \& Ilgen, D. R. 2006. Enhancing the effectiveness of work groups and teams. Psychological Science in the Public Interest, 7: 77-124.

Kozlowski, S. W., \& Klein, K. J. 2000. A multilevel approach to theory and research in organizations: Contextual, temporal, and emergent processes. In K. J. Klein \& S. W. Kozlowski (Eds.), Multilevel theory, research, and methods in organizations: Foundations, extensions, and new directions: 3-90. San Francisco: Jossey-Bass.

LaHuis, D. M., \& Ferguson, M. W. 2009. The accuracy of significance tests for slope variance components in multilevel random coefficient models. Organizational Research Methods, 12: 418-435.

LeBreton, J. M., \& Senter, J. L. 2008. Answers to 20 questions about interrater reliability and interrater agreement. Organizational Research Methods, 11: 815-852.

Lee, T. W., \& Mitchell, T. R. 1994. An alternative approach: The unfolding model of voluntary employee turnover. Academy of Management Review, 19: 51-89.

Lepak, D. P., Liao, H., Chung, Y., \& Harden, E. E. 2006. A conceptual review of human resource management systems in strategic human resource management research. Research in Personnel and Human Resources Management, 25: 217-271. 
Lorinkova, N., Pearsall, M., \& Sims, H. 2013. Examining the differential longitudinal performance of directive versus empowering leadership in teams. Academy of Management Journal, 56: 573-596.

Maloney, M. M., Johnson, S. G., \& Zellmer-Bruhn, M. E. 2010. Assessing group-level constructs under missing data conditions: A Monte Carlo simulation. Small Group Research, 41: 281-307.

March, J. G., \& Simon, H. A. 1958. Organizations. Oxford, England: Wiley.

Marks, M. A., Mathieu, J. E., \& Zaccaro, S. J. 2001. A temporally based framework and taxonomy of team processes. Academy of Management Review, 26: 356-376.

McCoach, D. B., \& Kaniskan, B. 2010. Using time-varying covariates in multilevel growth models. Frontiers in Psychology, 1(17). http://journal.frontiersin.org/article/10.3389/fpsyg.2010.00017/full

McElroy, J. C., Morrow, P. C., \& Rude, S. N. 2001. Turnover and organizational performance: A comparative analysis of the effects of voluntary, involuntary, and reduction-in-force turnover. Journal of Applied Psychology, 86: 1294-1299.

Meier, L. L., Semmer, N. K., Elfering, A., \& Jacobshagen, N. 2008. The double meaning of control: Three-way interactions between internal resources, job control, and stressors at work. Journal of Occupational Health Psychology, 13: 244-258.

Michel, J. G., \& Hambrick, D. C. 1992. Diversification posture and top management team characteristics. Academy of Management Journal, 35: 9-37.

Mitchell, T. R., \& James, L. R. 2001. Building better theory: Time and the specification of when things happen. Academy of Management Review, 26: 530-547.

Mobley, W. H. 1982. Some unanswered questions in turnover and withdrawal research. Academy of Management Review, 7: 111-116.

Moreland, R. L. 2010. Are dyads really groups? Small Group Research, 41: 251-267.

Murray, S. L., Holmes, J. G., Derrick, J. L., Harris, B., Griffin, D. W., \& Pinkus, R. T. 2013. Cautious to a fault: Selfprotection and the trajectory of marital satisfaction. Journal of Experimental Social Psychology, 49: 522-533.

Ng, T. W., \& Feldman, D. C. 2010. Organizational tenure and job performance. Journal of Management, 36: 12201250.

Nyberg, A. J., Moliterno, T. P., Hale, D., \& Lepak, D. P. 2014. Resource-based perspectives on unit-level human capital: A review and integration. Journal of Management, 40: 316-346.

Nyberg, A. J., \& Ployhart, R. E. 2013. Context-emergent turnover (CET) theory: A theory of collective turnover. Academy of Management Review, 38: 109-131.

O'Connor, K. M., Gruenfeld, D. H., \& McGrath, J. E. 1993. The experience and effects of conflict in continuing work groups. Small Group Research, 24: 362-382.

Park, T. Y., \& Shaw, J. D. 2013. Turnover rates and organizational performance: A meta-analysis. Journal of Applied Psychology, 98: 268-309.

Pearsall, M. J., Ellis, A. P., \& Stein, J. H. 2009. Coping with challenge and hindrance stressors in teams: Behavioral, cognitive, and affective outcomes. Organizational Behavior and Human Decision Processes, 109: 18-28.

Ployhart, R. E., Holtz, B. C., \& Bliese, P. D. 2002. Longitudinal data analysis: Applications of random coefficient modeling to leadership research. The Leadership Quarterly, 13: 455-486.

Ployhart, R. E., \& Moliterno, T. P. 2011. Emergence of the human capital resource: A multilevel model. Academy of Management Review, 36: 127-150.

Ployhart, R. E., \& Vandenberg, R. J. 2010. Longitudinal research: The theory, design, and analysis of change. Journal of Management, 36: 94-120.

Ployhart, R. E., \& Ward, A. K. 2011. The "quick start guide" for conducting and publishing longitudinal research. Journal of Business and Psychology, 26: 413-422.

Ployhart, R. E., Weekley, J. A., \& Ramsey, J. 2009. The consequences of human resource stocks and flows: A longitudinal examination of unit service orientation and unit effectiveness. Academy of Management Journal, 52: 996-1015.

Preacher, K. J., Curran, P. J., \& Bauer, D. J. 2006. Computational tools for probing interactions in multiple linear regression, multilevel modeling, and latent curve analysis. Journal of Educational and Behavioral Statistics, 31: 437-448.

Price, J. L. 1977. The study of turnover. Ames: Iowa State University Press.

Price, J. L. 1989. The impact of turnover on the organization. Work and Occupations, 16: 461-473.

Raes, A. M., Heijltjes, M. G., Glunk, U., \& Roe, A. 2006. Conflict, trust, and effectiveness in teams performing complex tasks: A study of temporal patterns. http://edocs.ub.unimaas.nl/loader/file.asp?id=1151. Accessed September 9, 2015. 
Reilly, G., Nyberg, A., Maltarich, M., \& Weller, I. 2013. Human capital flows: Using context-emergent turnover (CET) theory to explore the process by which turnover, hiring, and job demands affect patient satisfaction. Academy of Management Journal, 57: 766-790.

Roe, R. A. 2008. Time in applied psychology. European Psychologist, 13: 37-52.

Roe, R. A., Gockel, C., \& Meyer, B. 2012. Time and change in teams: Where we are and where we are moving. European Journal of Work and Organizational Psychology, 21: 629-656.

Rogosa, D. 1995. Myths and methods: "Myths about longitudinal research" plus supplemental questions. In J. Gottman (Ed.), The analysis of change, vol. 3: 3-65. Hillsdale, NJ: Erlbaum.

Shaw, J. D. 2011. Turnover rates and organizational performance: Review, critique, and research agenda. Organizational Psychology Review, 1: 187-213.

Shaw, J. D., Duffy, M. K., Johnson, J. L., \& Lockhart, D. E. 2005. Turnover, social capital losses, and performance. Academy of Management Journal, 48: 594-606.

Shaw, J. D., Gupta, N., \& Delery, J. E. 2005. Alternative conceptualizations of the relationship between voluntary turnover and organizational performance. Academy of Management Journal, 48: 50-68.

Simons, T. L., \& Peterson, R. S. 2000. Task conflict and relationship conflict in top management teams: The pivotal role of intragroup trust. Journal of Applied Psychology, 85: 102-111.

Singer, J. D., \& Willett, J. B. 2003. Applied longitudinal data analysis: Modeling change and event occurrence. New York: Oxford University Press.

Sonnentag, S. 2012. Time in organizational research: Catching up on a long neglected topic in order to improve theory. Organizational Psychology Review, 2: 361-368.

Spell, C. S., Bezrukova, K., Haar, J., \& Spell, C. 2011. Faultlines, fairness, and fighting: A justice perspective on conflict in diverse groups. Small Group Research, 42: 309-340.

Steffens, N. K., Shemla, M., Wegge, J., \& Diestel, S. 2014. Organizational tenure and employee performance a multilevel analysis. Group \& Organization Management, 39: 664-690.

Van der Vegt, G. S., Bunderson, S., \& Kuipers, B. 2010. Why turnover matters in self-managing work teams: Learning, social integration, and task flexibility. Journal of Management, 36: 1168-1191.

Wade, G. H. 1999. Professional nurse autonomy: Concept analysis and application to nursing education. Journal of Advanced Nursing, 30: 310-318.

Wall, J. A., \& Callister, R. R. 1995. Conflict and its management. Journal of Management, 21: 515-558.

Wittenbaum, G., Vaughan, S., \& Strasser, G. 1998. Coordination in task-performing groups. In R. Tindale, L. Heath, J. Edwards, E. Posavac, F. Bryant, Y. Suarez-Balcazar, E. Henderson-King, \& J. Myers (Eds.), Theory and research on small groups: 177-204. New York: Plenum Press. 